\title{
Endophytic fungal compounds active against Cryptococcus neoformans and C. gattii
}

\author{
Cristiane B Pereira $^{1}$, Djalma M de Oliveira $^{2}$, Alice FS Hughes ${ }^{1}$, Markus Kohlhoff ${ }^{3}$, Mariana LA Vieira ${ }^{1}$, \\ Aline B Martins Vaz ${ }^{1}$, Mariana C Ferreira ${ }^{1}$, Camila R Carvalho ${ }^{1}$, Luiz H Rosa ${ }^{1}$, Carlos A Rosa ${ }^{1}$, \\ Tânia MA Alves ${ }^{3}$, Carlos L Zani ${ }^{3}$, Susana Johann ${ }^{1}$ and Betania B Cota ${ }^{3}$
}

Infections with Cryptococcus are invasive mycoses associated with significant morbidity and mortality, mainly in immunosuppressed patients. Several drugs have been introduced to combat these opportunistic infections. However, resistance of this organism to antifungal drugs has increased, causing difficulties in the treatment. The goal of this work was to evaluate the antifungal activity of ethanol extracts from endophytic fungi isolated from plants collected from different Brazilian ecosystems and to perform the fractionation of the most promising extract. Four-hundred fungal extracts were investigated by microdilution broth assays against Cryptococcus neoformans and Cryptococcus gattii at a concentration of $500 \mu \mathrm{g} \mathrm{m} \mathrm{I}^{-1}$. Among them, the extract of Mycosphaerella sp. UFMGCB 2032, an endophytic fungus isolated from the plant Eugenia bimarginata DC. (Myrtaceae) exhibited outstanding antifungal activity against $C$. neoformans and $C$. gattii, with MIC values of $31.2 \mu \mathrm{ml}^{-1}$ and $7.8 \mu \mathrm{g} \mathrm{ml}^{-1}$, respectively. The fractionation of this extract using liquid-liquid partitioning and semi-preparative HPLC afforded two eicosanoic acids with antifungal activity, compound $1,(2 S, 3 R, 4 R)$-(E)-2-amino-3,4-dihydroxy-2-(hydroxymethyl)-14-oxoeicos6,12-dienoic acid with MIC values ranging from 1.3-2.50 $\mathrm{g} \mathrm{ml}^{-1}$, and compound 2, known as myriocin, with MIC values of $0.5 \mu \mathrm{g} \mathrm{ml}^{-1}$ against $C$. neoformans and $C$. gattii. These compounds are reported for the first time in the Mycosphaerella genus. The Journal of Antibiotics (2015) 68, 436-444; doi:10.1038/ja.2015.11; published online 25 February 2015

\section{INTRODUCTION}

Cryptococcosis is a systemic invasive mycosis associated with significant morbidity and mortality with worldwide distribution of some species. ${ }^{1,2}$ Cryptococcus neoformans and Cryptococcus gattii are the most important pathogenic species. ${ }^{3}$ Cryptococcosis is an opportunistic infection that affects immunosuppressed patients, whereas C. gattii yeasts may also affect immunocompetent individuals. ${ }^{1,4}$ Currently, the antifungal drugs used for cryptococcosis treatment are amphotericin B, 5 -flucytosine and fluconazole. However, the pharmacological management of the disease is difficult because of the complexity of the infections and treatments and the reports of resistance and/or tolerance to the antifungals and their toxic effects. ${ }^{5}$ The clinical syndromes and the treatment of infections caused by C. neoformans and C. gattii are very similar, but in some cases, a longer induction therapy may be required for a C. gattii infection. Moreover, this yeast has a propensity to promote massive inflammation. Mixed infections and drug resistance can occur, contributing to disease persistence and therapeutic failure. ${ }^{6,7}$ It is therefore expected that new classes of antifungal agents can help overcome these problems.

Endophytic microorganisms can live in the intra-and/or intercellular environments of plant tissues without causing any apparent negative effect to the plants. ${ }^{8}$ They are considered rich sources of bioactive natural products, ${ }^{9,10}$ which have been considered promising alternatives for a variety of human health concerns. ${ }^{10}$ Endophytic fungi associated with plants belonging to unique ecosystems, owing to environmental conditions, may produce specific secondary metabolites. ${ }^{9}$ In this view, Brazil has a rich diversity of plant species that may be associated with endophytic fungi communities and which remains poorly explored for antifungal activity. ${ }^{11}$ Ecosystems with unique characteristics such as microbial community, temperature, salinity and $\mathrm{pH}$ may contain many novel microorganisms species, including those able to produce compounds with undiscovered applications. ${ }^{9,10}$

The aim of the present study was to investigate the antifungal activity of crude ethanol extracts obtained from endophytic fungi associated with plants from different Brazilian ecosystems against the pathogenic yeasts C. neoformans and C. gattii, using a microbroth dilution susceptibility test and to perform the fractionation of the most promising extract. The present communication is concerned with the isolation and structural characterization of two eicosanoic-acid derivatives. These are antifungal compounds isolated and identified from the endophytic fungus Mycosphaerella sp., obtained from Eugenia

${ }^{1}$ Departamento de Microbiologia, Instituto de Ciências Biológicas, Universidade Federal de Minas Gerais, Belo Horizonte, MG, Brazil; ${ }^{2}$ Departamento de Química e Exatas, Universidade Estadual do Sudoeste da Bahia, Campus Universitário de Jequié, Jequié, Bahia, Brazil and ${ }^{3}$ Laboratório de Química de Produtos Naturais, Centro de Pesquisas René Rachou, Fundação Oswaldo Cruz, Belo Horizonte, MG, Brazil

Correspondence: Dr BB Cota, Laboratório de Química de Produtos Naturais, Centro de Pesquisas René Rachou, Fundação Oswaldo Cruz, Av Augusto de Lima 1715, Belo Horizonte, 30190-002 MG, Brazil.

E-mail: betania@cpqrr.fiocruz.br

Received 15 October 2014; revised 16 December 2014; accepted 19 January 2015; published online 25 February 2015 
bimarginata DC., a plant from the Myrtaceae family present in the Brazilian savannah.

\section{MATERIALS AND METHODS}

\section{Sources of endophytic fungi}

All plant samples were obtained from adult specimens collected in Brazil (savannah, Atlantic forest and Amazon rainforest). The plant identity, plant part collected, geographic coordinates and total number of endophytic fungi extracts evaluated are summarized in Table 1. Voucher specimens were deposited at the 'Instituto de Ciências Biológicas' herbarium (BHCB), 'Universidade Federal de Minas Gerais (ICB, UFMG)' and at the herbarium of 'Universidade Federal de Roraima', Brazil.

\section{Isolation of the endophytic fungi}

All samples of plant material were processed and the fungi was isolated as described previously. ${ }^{12}$ In brief, the tissue samples were cut into pieces, placed in sterilized individual plastic bags and stored for $<24 \mathrm{~h}$ at $10^{\circ} \mathrm{C}$ prior to the isolation of endophytic fungi. Before surface sterilization, the leaves were cut into $~ 5$-mm-long fragments using a flame-sterilized scalpel in a laminar flow hood to avoid air contamination of the tissues, and all samples were processed separately. The fragments were surface-sterilized by immersion in 2\% Extran (1 $\mathrm{min}), 70 \% \mathrm{EtOH}(1 \mathrm{~min})$ and $2 \%$ sodium hypochlorite $(3 \mathrm{~min})$, which was followed by a wash with sterile distilled water $(2 \mathrm{~min})$. Afterwards, the fragments were plated on Petri plates containing potato dextrose agar (PDA, Himedia, Mumbai, India) supplemented with chloramphenicol $\left(200 \mu \mathrm{g} \mathrm{ml}^{-1}\right)$ (Sigma, St Louis, MO, USA). The plates were incubated for up to 60 days at $25^{\circ} \mathrm{C}$, and the hyphal tip of each fungus growing out from the plant tissue was excised and transferred to a new PDA plate. After incubation at $25^{\circ} \mathrm{C}$ for 10 days, culture purity was assessed using colony morphology. To test the effectiveness of the surface sterilization, $100 \mu \mathrm{l}$ of the last water rinse was plated on PDA and incubated at $25^{\circ} \mathrm{C}$. Long-term samples of the filamentous fungal colonies were stored in cryotubes with $15 \%$ sterile glycerol at $-80^{\circ} \mathrm{C}$ and in sterile distilled water at room temperature. All endophytic fungal isolates were deposited in the Culture Collection of Microorganisms and Cells at the 'Universidade Federal de Minas Gerais' under the code UFMGCB.

\section{Fungi cultivation and extract preparation}

Two-millimeter-diameter plugs of each endophytic fungus culture were inoculated into the centers of Petri dishes $(90 \mathrm{~mm}$ diameter) containing $20 \mathrm{ml}$ of PDA and incubated at $25 \pm 2{ }^{\circ} \mathrm{C}$ for 15 days. The cultures were transferred to $50-\mathrm{ml}$ vial tubes containing $40 \mathrm{ml}$ of EtOH and macerated for $48 \mathrm{~h}$ at ambient temperature. The organic phase was decanted, and the solvent was removed in a vacuum centrifuge at $35^{\circ} \mathrm{C} .13$

\section{Bioassay}

Fungal isolates and inoculum. The antifungal activity of the extracts was evaluated using C. neoformans ATCC 24067 and C. gattii ATCC 24065. These yeast strains were stored frozen at $-80{ }^{\circ} \mathrm{C}$, and the inocula were prepared according to document 7.1.14 The starting inocula of Cryptococcus isolates were cultured onto Sabouraud dextrose agar twice for $48 \mathrm{~h}$ at $30^{\circ} \mathrm{C}$ to ensure purity and viability. The inoculum was prepared by picking five distinct colonies that were suspended in $5 \mathrm{ml}$ of sterile saline $(0.85 \%$ saline), and the resulting suspension transmittance was adjusted with a spectrophotometer to reach the 1.0 McFarland turbidity standard at $530 \mathrm{~nm}$ wavelength. This procedure yielded a yeast stock suspension of $1-5 \times 10^{6} \mathrm{CFU} \mathrm{ml}^{-1}$, from which was prepared a working suspension $\left(1-5 \times 10^{5} \mathrm{CFU} \mathrm{ml}^{-1}\right)$ in sterile distilled water.

\section{Screening for antifungal activity}

All crude extracts were diluted to a final concentration of $500 \mu \mathrm{g} \mathrm{ml}^{-1}$ in RPMI 1640 (InLab, São Paulo, Brazil) supplemented with $2 \%$ glucose (Vetec, Rio de Janeiro, Brazil) and MOPS (Sigma). Amphotericin B (Sigma) at $2.0 \mu \mathrm{g} \mathrm{ml}^{-1}$ was used as a positive control. The wells (except the blank control) were inoculated with the yeasts to obtain a final inoculum of $0.5-2.5 \times 10^{5}$ $\mathrm{CFU} \mathrm{m}{ }^{-1}$. The microplates were incubated at $30 \pm 2{ }^{\circ} \mathrm{C}$ for $48 \mathrm{~h}$, after which $10 \mu \mathrm{l}$ of a $5 \mathrm{mg} \mathrm{ml}^{-1}$ of MTT (3-(4,5-dimetylthiazol-2-yl)-2,5-diphenyltetrazolium bromide) (Amresco, Solon, OH, USA) solution was added to each well. The plates were then incubated for $4 \mathrm{~h}$ and the absorbance measured at $570 \mathrm{~nm}$ using a microtitre plate spectrophotometer (VERSAmax, Molecular Devices, Sunnyvale, CA, USA). ${ }^{13,14}$ The data were collected and analyzed using the instrument software (Softmax, Molecular Devices). The percentages of inhibition (\% inhib.) of the growth of the yeasts were calculated according to the following equation:

$$
\text { \%Inhib. }=\frac{(\text { OD of negative control well }- \text { OD of sample tested })}{\text { OD of negative control well }} \times 100
$$

Extracts with $75 \%$ inhibition of fungal growth against at least one Cryptococcus species were considered active. All susceptibility tests were performed in duplicate in three independent experiments.

\section{Determination of MIC}

The microdilution assays used to determinate the MIC were performed according to document 7.1 with modifications. ${ }^{14}$ The concentrations of the samples ranged from 500 to $0.97 \mu \mathrm{g} \mathrm{ml}^{-1}$. Fluconazole (Sigma) and amphotericin B (Sigma) were used as positive controls at concentrations of 0.125 to $64 \mu \mathrm{g} \mathrm{ml}^{-1}$ and $0.008^{-1} \mu \mathrm{g} \mathrm{ml}^{-1}$, respectively. MIC end points were defined as the lowest concentration of samples that inhibited yeast growth (yellow well) with inhibition equal or superior to $90 \%$ of the growth in the control well. ${ }^{14}$ All MIC values were obtained in duplicate in three independent experiments.

\section{Molecular identification of the fungal isolate UFMGCB 2032}

The internal transcribed spacer (ITS) region was amplified with the universal primers ITS1 and ITS4. ${ }^{15}$ The amplification of the ITS region was performed as described previously. ${ }^{16}$ Successfully amplified PCR products were purified using an ethanol/ethylenediaminetetraacetic acid precipitation protocol (Applied Biosystems, Foster City, CA, USA) and the sequencing reactions were performed at Myleus Biotechnology (www.myleus.com, Belo Horizonte, Brazil) on an ABI3130 automated sequencer (Applied Biosystems, Life Technologies, Foster City, CA, USA) using POP7 polymer and BigDye v3.1 with the same primers that were used in the amplification reactions. Quality control of individual sequences was performed by PHRED (http://asparagin.cenargen. embrapa.br/phph/), and only the sequences with at least 400 nucleotides and a PHRED quality score above 20 were considered. The consensus sequence was then generated by the CAP3 program (http://asparagin.cenargen.embrapa.br/ cgi-bin/phph/cap3.pl). ${ }^{17}$ The consensus sequence (PHRED $>20$ ) was subjected to phylogenetic inferences, which were estimated using MEGAVersion 5.0. ${ }^{18}$

Table 1 Host plant, data and number of extracts of endophytic fungi (EFE) assessed against Cryptococcus species

\begin{tabular}{|c|c|c|c|}
\hline Host plant & Collected part & Habitat and GPS location & Total of EFE \\
\hline Solanum cernuum & Leaves and stems & Atlantic forest $\left(19^{\circ} 52^{\prime} \mathrm{S}, 43^{\circ} 58^{\prime} \mathrm{W}\right)$ & 24 \\
\hline Eugenia bimarginata & Leaves & Savannah $\left(19^{\circ} 52^{\prime} \mathrm{S}, 43^{\circ} 58^{\prime} \mathrm{W}\right)$ & 7 \\
\hline Myrciaria floribunda & Leaves & Savannah $\left(09^{\circ} 20^{\prime} \mathrm{S}, 49^{\circ} 58^{\prime} \mathrm{W}\right)$ & 7 \\
\hline Alchornea castaneifolia & Leaves & Savannah $\left(09^{\circ} 20^{\prime} \mathrm{S}, 49^{\circ} 58^{\prime} \mathrm{W}\right)$ & 21 \\
\hline Stryphnodendron adstrigens & Leaves and stems & Savannah $\left(21^{\circ} 05^{\prime} \mathrm{S}, 44^{\circ} 12^{\prime} \mathrm{W}\right)$ and $\left(19^{\circ} 30^{\prime} \mathrm{S}, 4^{\circ} 54^{\prime} \mathrm{W}\right)$ & 151 \\
\hline Carapa guianensis & Leaves & Amazon rainforest $\left(0^{\circ} 57^{\prime} 02^{\prime \prime} \mathrm{N}, 59^{\circ} 54^{\prime} 41^{\prime \prime} \mathrm{W}\right)$ & 194 \\
\hline
\end{tabular}


The alignments were prepared including sequences of all relevant type strains or reference strains from culture collections deposited in GenBank to ensure accurate identification. The sequences were aligned using the MUSCLE method ${ }^{19}$ with manual adjustments for visual improvement where necessary. The Akaike information criterion was used to identify the most appropriate model of evolution for the data set. For ITS sequences, the data were estimated using the maximum likelihood method based on the general time reversible model, and a discrete gamma distribution was used to model evolutionary rate differences among sites (five categories $(+\mathrm{G}$, parameter $=0.5758$ ). The rate variation model allowed some sites to be evolutionarily invariable $((+\mathrm{I}), 0.00 \%$ sites). The robustness of the trees was estimated by a bootstrap analysis ${ }^{20}$ with 1000 replicates. The consensus sequence was submitted to GenBank and assigned an accession number from KF681521.

\section{General experimental procedures}

Thin layer chromatography analyses were conducted on pre-coated silica gel G-60/F 254 plates $(0.25 \mathrm{~mm}$, Merck, Darmstadt, Germany). Thin layer chromatography plates were eluted in a pre-saturated chamber using mixtures with different proportions of $\mathrm{CHCl}_{3}: \mathrm{MeOH}: \mathrm{NH}_{4} \mathrm{OH}$. The spots were visualized under visible and UV light $(254 \mathrm{~nm}$ and $366 \mathrm{~nm})$, and after heating the plate was sprayed with vanillin- $\mathrm{H}_{2} \mathrm{SO}_{4}$ reagent. Analytical reversed phase-HPLC analyses were run in a HPLC system (Shimadzu, Kyoto, Japan) equipped with a LC6AD pump and a SPD M-10 A VP diode-array detector. Analytical analyses were carried out on a Shim-pack C18 column $(5 \mu \mathrm{m}, 4.6 \mathrm{~mm} \times 250 \mathrm{~mm}$, internal diameter) eluted with a gradient of $\mathrm{CH}_{2} \mathrm{CN}: \mathrm{H}_{2} \mathrm{O}$ at a flow rate of $1 \mathrm{ml} \mathrm{min}^{-1}$. Semi-preparative purifications were done on a Shim-pack $\mathrm{C} 18$ column $\left(5 \mu \mathrm{m}, 20 \times 250 \mathrm{~mm}\right.$, internal diameter) using mixtures of $\mathrm{MeOH}: \mathrm{H}_{2} \mathrm{O}$ or $\mathrm{CH}_{2} \mathrm{CN}: \mathrm{H}_{2} \mathrm{O}$ as eluents. The flow rate was set at $8 \mathrm{ml} \mathrm{min}^{-1}$ and the effluent absorption measured at $220 \mathrm{~nm}$ on a Shimadzu SPD-10 A-UV detector (Shimadzu). Solvents were removed using a vacuum centrifuge (ThermoSavant SPD SC250 Express, Holbrook, NY, USA). UV spectrum was recorded in $\mathrm{MeOH}$ on a Beckman DU Series 600 spectrophotometer (Beckman Instruments, Fullerton, CA, USA) and optical rotations were determined on a Modular Circular Polarimeter MCP 300 (Anton Paar, Ashland, VA, USA).

\section{Large-scale cultivation and extraction procedures}

Five 2-mm-diameter plugs of the culture of Mycosphaerella sp. were inoculated into each of 600 Petri dishes (90-mm diameter) containing $20 \mathrm{ml}$ of PDA. The plates were incubated at $25 \pm 2{ }^{\circ} \mathrm{C}$ for 15 days. The mycelium was separated from the medium with a spatula and both the medium and mycelium were extracted four times at $48 \mathrm{~h}$ intervals using ethyl acetate. The organic phases were grouped and concentrated on a rotary evaporator. The residual solvent was removed on a vacuum centrifuge at $40^{\circ} \mathrm{C}$ to yield the crude extracts. These extracts were diluted in a $\mathrm{MeOH}: \mathrm{H}_{2} \mathrm{O}$ mixture (1:3) and successively partitioned between hexane (Hex), dichloromethane (DCM) and ethyl acetate (EtOAc). This procedure afforded the organic fractions denominated as hexane, dichloromethane and EtOAc, and Aqueous (Aq).

Isolation of antifungal compounds. An 800-mg portion of the EtOAc fraction residue was dissolved in $\mathrm{MeOH}: \mathrm{H}_{2} \mathrm{O}$ (1:1) and then centrifuged to remove suspended and insolubilized material. Nine aliquots containing $\sim 100 \mathrm{mg}$ of extract were injected into the semi-prep column. The column was eluted with a linear gradient of $\mathrm{MeOH}$ in $\mathrm{H}_{2} \mathrm{O}$ starting at $10 \%$ and going to $50 \%$ in $30 \mathrm{~min}$, from 50 to $95 \%$ in $20 \mathrm{~min}$, from 95 to $100 \%$ in $1 \mathrm{~min}$, and held at $100 \%$ for $17 \mathrm{~min}$. Twenty-eight sub-fractions were obtained and tested in an antifungal assay. Active sub-fractions $13(41 \mathrm{mg})$ and $14(59 \mathrm{mg})$ were further fractionated by semi-preparative reversed phase-HPLC. The elution started with $\mathrm{CH}_{2} \mathrm{CN}$ : $\mathrm{H}_{2} \mathrm{O} 30 \%$ during $10 \mathrm{~min}$, and the $\mathrm{CH}_{2} \mathrm{CN}$ proportion increased to $50 \%$ in $14 \mathrm{~min}, 75 \%$ in $26 \mathrm{~min}$, and then to $100 \%$ in $10 \mathrm{~min}$ and kept at $100 \%$ for $30 \mathrm{~min}$. Sub-fraction 13 yielded $12 \mathrm{mg}$ of compound 1 , whereas sub-fraction 14 afforded $21.5 \mathrm{mg}$ of compound 2 .

\section{Spectral data of the isolated compounds}

One- and two-dimensional NMR experiments were run on a Bruker Avance $400 \mathrm{MHz}$ spectrometer with standard pulse sequences using deuterated solvents containing $0.1 \%$ tetramethylsilane.

LC-DAD-MS analyses were performed using a Thermo Surveyor Plus chromatograph (Thermo Fisher Scientific, Waltham, MA, USA) equipped with a Finnigan Surveyor PDA Plus diode-array detector. The analysis was carried out on a reverse phase column (Atlantis C18, Waters, Milford, USA, $3 \mu \mathrm{m}$ particle diameter, $150 \mathrm{~mm} \times 2.1 \mathrm{~mm}$ i.d.) using a linear gradient of $\mathrm{CH}_{2} \mathrm{CN}$ :

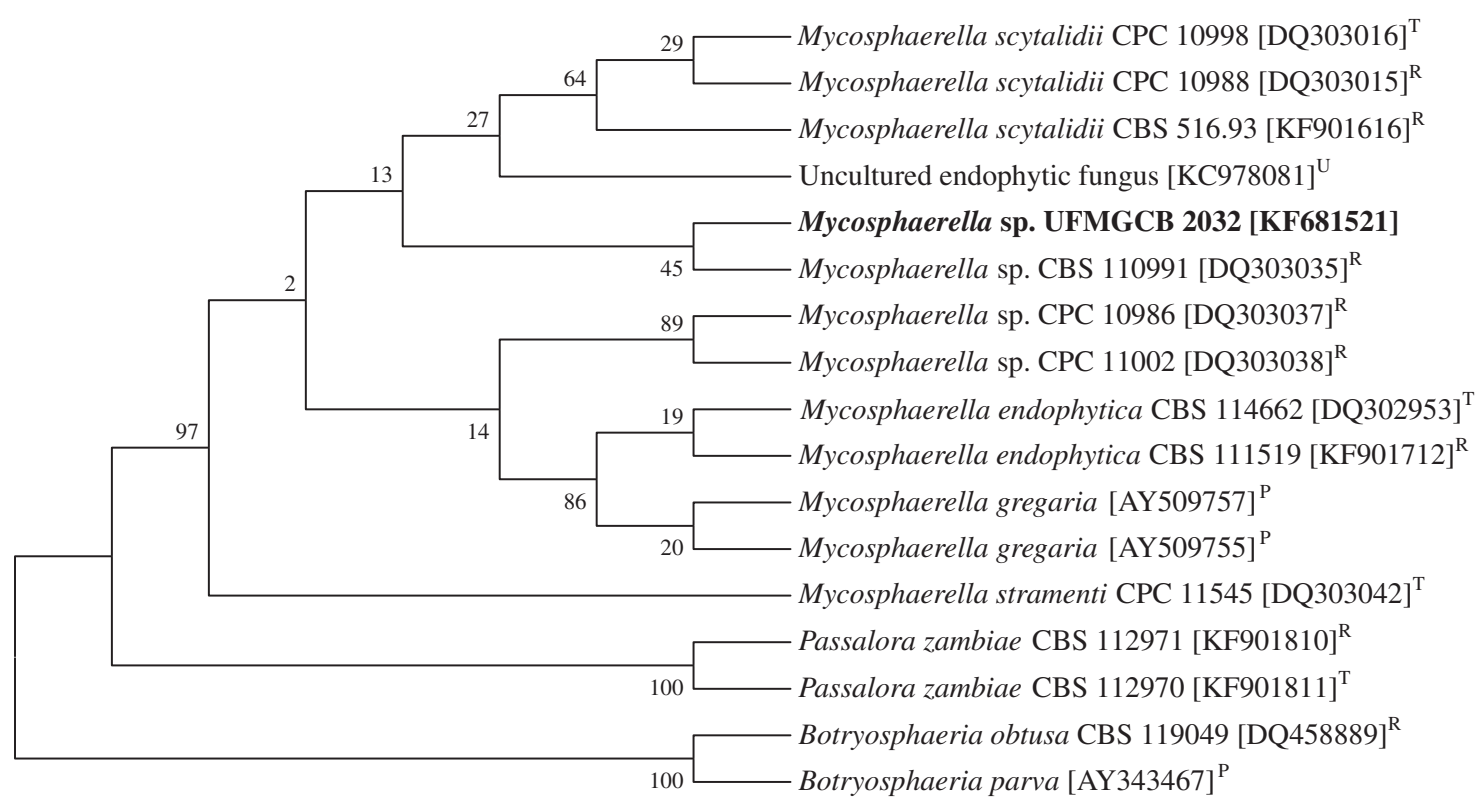

Figure $1 \mathrm{~A}$ consensus tree representing the phylogenetic analysis of the ITS region sequences of mycelia fungus (name and (accession number) in bold) isolates from Eugenia bimarginata DC. (Myrtaceae), in comparison with T (type strain), R (reference strains), P (from publications) or U (Unpublished) of the closest species (Mycosphaerella sp. (accession no.)), following BLAST analysis, deposited in the GenBank database. The tree was rooted with Passalora zambiae, Botryosphaeria obtusa and Botryosphaeria parva as the outgroup. Numbers at the branches are the bootstrap values of 1000 replications. There were a total of 726 positions in the final data set. The tree was constructed using MEGA software with the maximum composite likelihood method. 
$\mathrm{H}_{2} \mathrm{O}$ from 1 to $100 \%$ in $12.5 \mathrm{~min}$. The effluent was entirely directed to the Bruker ETD-maXis quadrupole time-of-flight (Q-TOF) (Bruker Daltonics, Bremen, Germany) for ESI in the positive and negative ion modes. The mass detector was set to the $\mathrm{m} / \mathrm{z}$ range $50-1500 \mathrm{Da}$. The instrument was operated under the following conditions: end plate offset, $-500 \mathrm{~V}$; capillary voltage, $4500 \mathrm{~V}$; nebulizer pressure, 0.4 bar; dry gas (nitrogen) flow rate, $4.01 \mathrm{~min}^{-1}$; dry temperature, $180^{\circ} \mathrm{C}$; in-source collision-induced dissociation energy, $25 \mathrm{eV}$; collision energy, $7 \mathrm{eV}$; ion cooler RF, $25 \mathrm{Vpp}$ and transfer time, 45-49 $\mu \mathrm{s}$.

\section{RESULTS AND DISCUSSION}

Screening for antifungal activity toward Cryptococcus species Although endophytic fungi have been studied as producers of antifungal natural products, screenings against Cryptococcus as the main target using microdilution broth assays have been underexplored. ${ }^{21,22}$ In our continued search for new compounds with antifungal activity from endophytic fungi, ${ }^{11,13,23-25}$ attention was focused on the ethanol extracts of the endophytic fungi isolated from six plants growing in different Brazilian ecosystems (Table 1). They yielded 404 extracts that were tested at $500 \mu \mathrm{g} \mathrm{ml}^{-1}$ against C. neoformans and C. gattii. Four extracts (1.2\% of isolates) showed $>75 \%$ inhibition of fungal growth against at least one Cryptococcus species.

Table 2 MIC values of samples from Mycosphaerella sp. UFMGCB 2032 against Cryptococcus neoformans ATCC 24067 and Cryptococcus gattii ATCC 24065 using microdilution broth assays

\begin{tabular}{lcc}
\hline Sample & $\begin{array}{c}\text { C. neoformans } \\
\text { MIC }\left(\mu \mathrm{g} \mathrm{m} /^{-1}\right)\end{array}$ & $\begin{array}{c}\text { C. gatti } \\
\text { MIC }\left(\mu g \mathrm{I}^{-1}\right)\end{array}$ \\
\hline EtOAc crude extract & 31.2 & 7.8 \\
Hex fraction & 500 & 62.5 \\
DCM fraction & 500 & $>500$ \\
EtOAc fraction & 31.2 & 7.8 \\
Aq fraction & 500 & $>500$ \\
Compound 1 & 1.3 & 2.5 \\
Compound 2 & 0.5 & 0.5 \\
Amphotericin B & 0.5 & 0.3 \\
Fluconazole & 4.0 & 4.0 \\
\hline
\end{tabular}

The MIC value of the extract from UFMGCB $2032\left(7.8 \mu \mathrm{g} \mathrm{ml}^{-1}\right)$ was close to that observed for fluconazole $\left(4.0 \mu \mathrm{g} \mathrm{ml}^{-1}\right)$ in the assay with $C$. gattii. Fluconazole is a major antifungal agent used in the treatment of cryptococcosis because of its high efficacy, low toxicity and ability to be administered orally and parentally. ${ }^{26}$ Therefore, the isolate UFMGCB 2032 was chosen to be submitted to chromatographic fractionation with the aim of identifying its antifungal compounds.

\section{Identification of fungal isolate UFMGCB 2032}

The identification of the fungal isolate UFMGCB 2032 was based on the analysis of the ITS region because it was not possible to obtain sporulating cultures with the specific conditions and culture media used to perform the morphological identification technique. The nucleotide sequence of UFMGCB 2032 did not show 100\% alignment and $100 \%$ identity with any species deposited in GenBank. Other nuclear genomic loci such as $\beta$-tubulin and translation elongation factor 1-alpha were used to identify the isolate, but the amplification success rate failed to amplify these loci. The sequence of the fungus UFMGCB 2032 showed identity and coverage ranging from 99 to $98 \%$, with sequences of uncultured endophytic and different species of Mycosphaerella; for this reason the fungal isolate was identified only at the genus level. The related sequences from the ITS region of the ribosomal RNA were retrieved from GenBank and were used for the phylogenetic analysis with MEGA 5 using the neighbor-joining method with 1000 bootstrap replicates. The phylogenetic analysis confirmed the distinct clustering of the isolate obtained in the study with Mycosphaerella species as the closest genotypes to the fungal isolate (Figure 1).

\section{Chromatographic fractionation of Mycosphaerella sp. extract}

The endophytic fungus Mycosphaerella sp. (UFMGCB 2032) was isolated from E. bimarginata, a plant from the Brazilian savannah. A literature search revealed that species of the Eugenia genus have some interesting properties such as antioxidant, anti-inflammatory, cytotoxic, anti-Trypanosoma cruzi, hypoglycemic and hypocholesterolemic activities. ${ }^{27-30}$ In addition, antifungal activities have also been reported for a few species of the genus Eugenia. Clove oleoresin from Eugenia caryophyllata has shown fungicidal activity against Candida albicans, Penicillium citrinum, Aspergillus niger and<smiles>CCCCCCC(=O)C=CCCCCC=CCC(O)[C@H](O)[C@@](N)(CO)C(=O)O</smiles><smiles>CCCCCCC(=O)CCCCCC/C=C/C[C@@H](O)[C@@H](O)[C@](N)(CO)C(=O)O</smiles>

(2)

Figure 2 Structures of the compounds isolated from Mycosphaerella sp UFMGCB 2032. A full color version of this figure is available at The Journal of Antibiotics journal online. 
Table 3 Physicochemical properties of compound 1

\begin{tabular}{lc}
\hline Properties & Compound 1 \\
\hline Appearance & White powder \\
Molecular formula & $\mathrm{C}_{21} \mathrm{H}_{37} \mathrm{NO}_{6}$ \\
HRMS (ESI-QTOF) $(\mathrm{m} / \mathrm{z})$ & \\
Found & $398.2533[\mathrm{M}-\mathrm{H}]^{-}$ \\
$\mathrm{Calcd}$ for $\mathrm{C}_{21} \mathrm{H}_{36} \mathrm{NO}_{6}$ & 398.2543 for $[M-\mathrm{H}]^{-}$ \\
$\mathrm{UV} \lambda \mathrm{MeOH}^{-} \mathrm{nm}(\mathrm{Log} \varepsilon)_{\mathrm{max}}$ & $227(2.55)$ \\
{$[\alpha]_{D}{ }^{25}(\mathrm{C} \mathrm{O} .3 \mathrm{MeOH})$} & -9.0 \\
Soluble & DMSO, methanol \\
\hline
\end{tabular}

Trichophyton mentagrophytes. ${ }^{31}$ Essential oil from Eugenia uniflora L. was active toward several species of opportunistic pathogens belonging to the genera Candida (MIC 37.5-2.3 $\mu \mathrm{g} \mathrm{ml}^{-1}$ ) and Cryptococcus, including C. gattii (MIC 18.0-22.0 $\mu \mathrm{g} \mathrm{m}^{-1}$ ) and C. neoformans (MIC $11.0 \mu \mathrm{g} \mathrm{ml}^{-1}$ ). In this study, the major constituents of Eugenia uniflora L. essential oil, identified by analysis by GC-MS, are the sesquiterpenes atractylone $(26.78 \%)$ and curzerene $(17.96 \%) .{ }^{27}$

The ethyl acetate extract of Mycosphaerella sp. mycelium grown in PDA medium exhibited MIC values of $31.2 \mu \mathrm{g} \mathrm{ml}^{-1}$ against C. neoformans and $7.8 \mu \mathrm{g} \mathrm{ml}^{-1}$ against C. gattii (Table 2), respectively. The extract was subjected to a liquid-liquid partition sequence, and

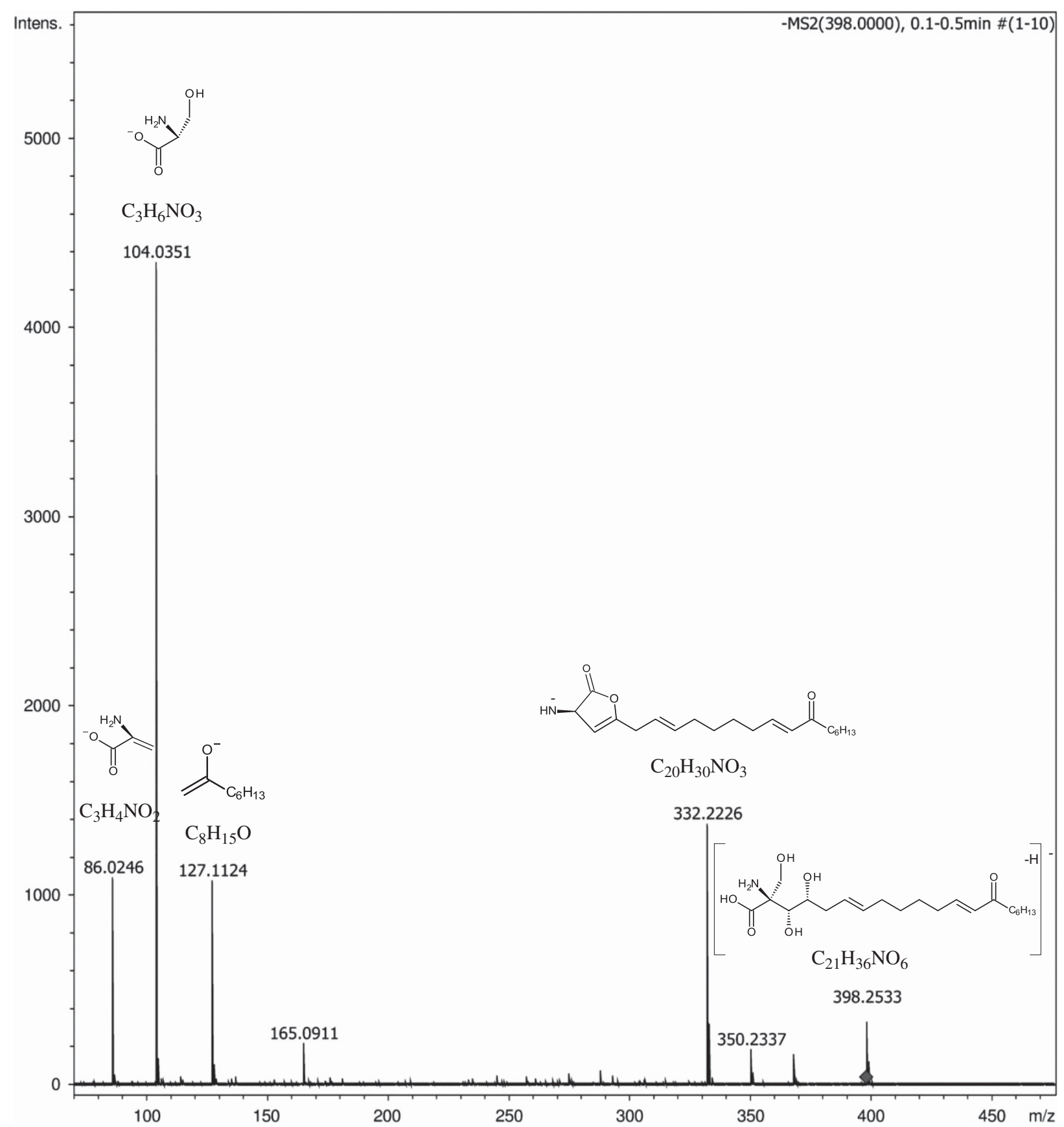

Figure 3 The ESI-(-)-LC-MS/MS spectra of compound 1 and proposal of the key fragments. A full color version of this figure is available at The Journal of Antibiotics journal online. 
this procedure afforded four fractions: hexane, dichloromethane, EtOAc and Aq. They were tested against the two Cryptococcus species and the results showed that the EtOAc fraction exhibited MIC values comparable to the crude extract (Table 2). In order to identify its active compounds, the EtOAc fraction was chromatographed twice by semi-preparative reverse phase HPLC to afford two active compounds (1 and 2) (Figure 2).

\section{Structural elucidation of the active compounds isolated from Mycosphaerella sp.}

The chemical structures of compounds 1 and 2 were established by analysis of NMR and mass spectrometric data and their comparison with the literature data. Compound $\mathbf{1}$ was isolated as an amorphous white solid with a specific rotation $[\alpha]_{\mathrm{D}}{ }^{25}-9.0^{\circ}$ (c 0.3 in $\mathrm{MeOH}$ ) (Table 3$)$. It gives a reddish-brown spot $\left(R_{\mathrm{f}}=0.45 ; \mathrm{CHCl}_{3}: \mathrm{MeOH}\right.$ : $\left.\mathrm{NH}_{4} \mathrm{OH} / 10: 6.25: 0.25\right)$ after spraying the plates with vanillin $-\mathrm{H}_{2} \mathrm{SO}_{4}$. The negative high-resolution mass spectra (HRMS) (ESI-quadrupole time-of-flight (QTOF)) spectrum showed a quasi-molecular ion peak $[M-\mathrm{H}]^{-}$at $\mathrm{m} / \mathrm{z} 398.2533$ (calcd. 398.2543 for $\mathrm{C}_{21} \mathrm{H}_{36} \mathrm{NO}_{6}$ ), consistent with the molecular formula $\mathrm{C}_{21} \mathrm{H}_{37} \mathrm{NO}_{6}$. The mass spectrum obtained using tandem MS of compound $\mathbf{1}$ gave a base peak at $\mathrm{m} / \mathrm{z}$ $104.0351\left(\mathrm{C}_{3} \mathrm{H}_{6} \mathrm{NO}_{3}\right)$ attributed to the fragment $[\mathrm{M}-\mathrm{H}-294]^{-}$, and major fragments at $m / z 332.2226\left(\mathrm{C}_{20} \mathrm{H}_{30} \mathrm{NO}_{3}\right), \mathrm{m} / z \quad 127.1124$ $\left(\mathrm{C}_{8} \mathrm{H}_{15} \mathrm{O}\right)$ and $\mathrm{m} / z 86.0246\left(\mathrm{C}_{3} \mathrm{H}_{4} \mathrm{NO}_{2}\right)$. The proposal of the key fragments is shown in Figure 3. The UV spectrum of 1 showed $\lambda_{\max }$ at $227 \mathrm{~nm}$. NMR spectra (one and two dimensional) showed ${ }^{1} \mathrm{H}$ signals characteristic of a hydrocarbon chain at $\delta 2.54-1.21$, corresponding to methylene carbons at $\delta 39.0-21.9$ in the ${ }^{13} \mathrm{C}$ spectrum. Furthermore, the ${ }^{13} \mathrm{C}$ NMR spectrum of compound 1 showed peaks owing to four olefinic carbons resonating at $\delta 147.1$ and 130.2, 131.6 and 127.0. These peaks were correlated to four olefinic protons at $\delta 6.83,6.07$, 5.43 and 5.35 in the ${ }^{1} \mathrm{H}$ NMR spectrum (Table 4). The geometry of the $\mathrm{C}_{6} / \mathrm{C}_{7}$ and $\mathrm{C}_{12} / \mathrm{C}_{13}$ alkene bonds were trans $(E)$, as evidenced by the large vicinal coupling constants $\left(J_{6-7}=15.5 \mathrm{~Hz}\right.$ and $J_{12-13}=16.0 \mathrm{~Hz}$ ). The ${ }^{13} \mathrm{C}$ NMR (DEPT) spectrum of 1 showed signals at $\delta 200.0$ and at $\delta 169.9$ of carbonyl carbons; the former was attributed to a ketone group and the latter to a carboxylic acid group. Correlation peaks between the $\mathrm{H}-13(\delta 6.07)$ and $\mathrm{H}-15(\delta$ 2.54) signals and the carbonyl at $\delta 200.0$ in HMBC were observed and confirmed the location of the ketone group. HMBC correlations of the carboxylic acid carbonyl group at $\delta 169.9$ confirmed its position at C-1 owing to cross peaks with $\mathrm{H}-2^{\prime}(\delta 3.56$ and $\delta 3.69)$. The doublets at $\delta 3.69(1 \mathrm{H}$, $\left.\mathrm{d}, J=10.5, \mathrm{H}-2^{\prime} \mathrm{a}\right)$ and $\delta 3.56\left(1 \mathrm{H}, \mathrm{d}, J=10.5, \mathrm{H}-2^{\prime} \mathrm{b}\right)$ were attributed to the geminal hydrogens of an oxygenated primary carbon. In addition, the ${ }^{1} \mathrm{H}$ NMR spectrum showed signals for two protons bound to the oxygenated tertiary carbons at $\delta 3.64(1 \mathrm{H}, t d, J 7.0,1.5$, $\mathrm{H}-4)$ and $\delta 3.61(1 \mathrm{H}, b r s, \mathrm{H}-3)$. The values of the coupling constants of the signals at $\delta 3.64$ and at $\delta 3.61$ are similar to the values published for natural mycestericin $\mathrm{A}^{32}$ and synthetic myriocin. ${ }^{33,34}$ The ${ }^{1} \mathrm{H}-{ }^{1} \mathrm{H}$ COSY cross-peak between $\mathrm{H}-4(\delta 3.64)$ and $\mathrm{H}-5$ ( $\delta 2.09)$ suggests their vicinal location. The ${ }^{1} \mathrm{H}$ NMR and ${ }^{13} \mathrm{C}$ NMR spectral data of compound 1 exhibited the characteristic signals of aliphatic chains

Table 4 NMR data for compounds 1 and 2 (DMSO-d6) at 400/100 MHz, $\delta$ in ppm and $J$ in $\mathrm{Hz}$

\begin{tabular}{|c|c|c|c|c|c|c|c|c|}
\hline \multirow[b]{2}{*}{ Position } & \multicolumn{4}{|c|}{ Compound 1} & \multicolumn{4}{|c|}{ Compound 2} \\
\hline & $\delta^{13} C(D E P T)$ & $\delta^{1} H(J)$ & ${ }^{1} \mathrm{H}^{1}{ }^{1} \mathrm{HCOSY}$ & $H M B C(H \rightarrow C)$ & ${ }^{13} C(D E P T)$ & $\delta^{1} H(J)$ & ${ }^{1} \mathrm{H}^{1}{ }^{\mathrm{H}} \mathrm{COSY}$ & $H M B C(H \rightarrow C)$ \\
\hline 1 & $169.9(\mathrm{C})$ & & & $\mathrm{H}-2^{\prime} \mathrm{a}, \mathrm{H}-2^{\prime} \mathrm{b}$ & $169.7(\mathrm{C})$ & & & $H-2^{\prime} a, H-2^{\prime} b$ \\
\hline 2 & $67.6(C)$ & & & $\mathrm{H}-2^{\prime}, \mathrm{H}-3$ & $67.8(\mathrm{C})$ & & & \\
\hline 3 & $69.3(\mathrm{CH})$ & $3.61(b r s)$ & & & $69.3(\mathrm{CH})$ & $3.61(b r s)$ & & \\
\hline $3-\mathrm{OH}$ & & $5.02(b r s)^{\mathrm{a}}$ & & & & $5.02(b r s)^{\mathrm{a}}$ & $\mathrm{H}-3$ & \\
\hline 4 & $70.7(\mathrm{CH})$ & $3.64(t d, J 7.0,1.5)$ & $\mathrm{H}-5$ & & $70.7(\mathrm{CH})$ & $3.64(t d, J 7.0,1.5)$ & $H-5$ & \\
\hline 5 & $37.5\left(\mathrm{CH}_{2}\right)$ & $\begin{array}{c}\text { a: } 2.09(d d d, J 7.0) \\
\text { b: } 2.16(m)\end{array}$ & $\mathrm{H}-4, \mathrm{H}-6, \mathrm{H}-7$ & & $37.5\left(\mathrm{CH}_{2}\right)$ & $\begin{array}{l}\text { a: } 2.09(d d d, \text { J 7.0) } \\
\text { b: } 2.15(d d d, \text { J 7.0) }\end{array}$ & $\begin{array}{c}H-5 b, H-6 \\
H-5 a\end{array}$ & $\mathrm{H}-4, \mathrm{H}-6, \mathrm{H}-7$ \\
\hline 6 & $131.6(\mathrm{CH})$ & $5.43(d t, J 15.5,6.5)$ & $\mathrm{H}-5, \mathrm{H}-7$ & $\mathrm{H}-8$ & $131.9(\mathrm{CH})$ & $5.42(d t, J) 15.3,6.5)$ & $\mathrm{H}-7, \mathrm{H}-8$ & $\mathrm{H}-8$ \\
\hline 7 & $127.0(\mathrm{CH})$ & $5.35(d t, J 15.5,6.5)$ & $\mathrm{H}-6, \mathrm{H}-8$ & H-8 & $126.7(\mathrm{CH})$ & $5.34(d t, J 15.4,6.5)$ & $\mathrm{H}-5, \mathrm{H}-6, \mathrm{H}-8$ & $\mathrm{H}-8$ \\
\hline 8 & $31.8\left(\mathrm{CH}_{2}\right)$ & $1.96(\operatorname{br} q, \mathrm{~J} 6.5)$ & $\mathrm{H}-7$ & $\mathrm{H}-6, \mathrm{H}-7$ & $32.1\left(\mathrm{CH}_{2}\right)$ & $1.93(q, \mathrm{~J} 6.7)$ & $\mathrm{H}-6, \mathrm{H}-10$ & $\mathrm{H}-6, \mathrm{H}-7$ \\
\hline 9 & $28.4\left(\mathrm{CH}_{2}\right)$ & $1.34($ br q, J 7.5) & $\mathrm{H}-8$ & $\mathrm{H}-8, \mathrm{H}-10$ & $28.4\left(\mathrm{CH}_{2}\right)^{\mathrm{b}}$ & $1.31-1.29(m)^{\mathrm{a}}$ & $\mathrm{H}-8$ & \\
\hline 10 & $27.0\left(\mathrm{CH}_{2}\right)$ & $1.42(b r q, 7.5)$ & $\mathrm{H}-11$ & $\mathrm{H}-8, \mathrm{H}-9, \mathrm{H}-11$ & $28.8\left(\mathrm{CH}_{2}\right)$ & $1.28-1.27(m)^{\mathrm{a}}$ & $\mathrm{H}-8$ & $\mathrm{H}-8$ \\
\hline 11 & $31.6\left(\mathrm{CH}_{2}\right)$ & $2.19(b r q, J 7.0)$ & $\mathrm{H}-10, \mathrm{H}-12, \mathrm{H}-13$ & $\mathrm{H}-12, \mathrm{H}-13$ & $28.3\left(\mathrm{CH}_{2}\right)^{\mathrm{b}}$ & $1.26-1.25(m)^{\mathrm{a}}$ & $\mathrm{H}-10$ & $\mathrm{H}-9, \mathrm{H}-12$ \\
\hline 12 & $147.1(\mathrm{CH})$ & $\begin{array}{c}6.83(b r d t, J 16.0 \\
7.0)\end{array}$ & $\mathrm{H}-11, \mathrm{H}-13$ & $\mathrm{H}-11$ & $23.2\left(\mathrm{CH}_{2}\right)$ & 1.44 (qui, J 7.0) & $\mathrm{H}-13$ & $\mathrm{H}-11, \mathrm{H}-13$ \\
\hline 13 & $130.2(\mathrm{CH})$ & $6.07(d t, J 16.0,2.0)$ & $\mathrm{H}-11, \mathrm{H}-12$ & $\mathrm{H}-11$ & $41.8\left(\mathrm{CH}_{2}\right)$ & $2.38(t, J 7.2)$ & $\mathrm{H}-12$ & $\mathrm{H}-12$ \\
\hline 14 & $200.0(C)$ & - & & $\mathrm{H}-12, \mathrm{H}-13, \mathrm{H}-15$ & $210.58(\mathrm{C})$ & & & $\begin{array}{c}\mathrm{H}-12, \mathrm{H}-13, \mathrm{H}-15, \\
\mathrm{H}-16\end{array}$ \\
\hline 15 & $39.0\left(\mathrm{CH}_{2}\right)$ & $2.54(t, J 7.3)$ & $\mathrm{H}-16$ & $\mathrm{H}-16$ & $41.8\left(\mathrm{CH}_{2}\right)$ & $2.38(t, J 7.2)$ & $\mathrm{H}-16$ & $\mathrm{H}-16$ \\
\hline 16 & $23.7\left(\mathrm{CH}_{2}\right)$ & 1.47 (br quin, J 7.0) & $\mathrm{H}-15, \mathrm{H}-18$ & $\mathrm{H}-15$ & $23.2\left(\mathrm{CH}_{2}\right)$ & 1.44 (qui, J 7.1) & $\mathrm{H}-15, \mathrm{H}-17$ & $\mathrm{H}-15$ \\
\hline 17 & $28.2\left(\mathrm{CH}_{2}\right)$ & $1.23-1.21(m)^{\mathrm{a}}$ & & $\mathrm{H}-15, \mathrm{H}-16$ & $28.5\left(\mathrm{CH}_{2}\right)^{\mathrm{b}}$ & $1.22-1.20(m)^{\mathrm{a}}$ & $\mathrm{H}-16$ & $\mathrm{H}-15, \mathrm{H}-16$ \\
\hline 18 & $31.0\left(\mathrm{CH}_{2}\right)$ & $1.26-1.24(m)^{\mathrm{a}}$ & $\mathrm{H}-16, \mathrm{H}-20$ & $\mathrm{H}-16, \mathrm{H}-19, \mathrm{H}-20$ & $31.1\left(\mathrm{CH}_{2}\right)$ & $1.24-1,23(m)^{\mathrm{a}}$ & $\mathrm{H}-20$ & $\mathrm{H}-19, \mathrm{H}-20$ \\
\hline 19 & $21.9\left(\mathrm{CH}_{2}\right)$ & $1.30-1.27(m)^{\mathrm{a}}$ & $\mathrm{H}-20$ & $\mathrm{H}-17, \mathrm{H}-20$ & $21.9\left(\mathrm{CH}_{2}\right)$ & $1.26-1.25(m)^{\mathrm{a}}$ & $\mathrm{H}-20$ & $\mathrm{H}-17, \mathrm{H}-20$ \\
\hline 20 & $13.9\left(\mathrm{CH}_{3}\right)$ & $0.85(t, J 7.0)$ & $\mathrm{H}-18, \mathrm{H}-19$ & H-18 & $13.9\left(\mathrm{CH}_{3}\right)$ & $0.85(t, J 7.0)$ & $\mathrm{H}-19$ & H-18 \\
\hline $2^{\prime} \mathrm{a}$ & $62.4\left(\mathrm{CH}_{2}\right)$ & a: $3.69(d, J 10.5)$ & $H-2$ 'b & & $62.4\left(\mathrm{CH}_{2}\right)$ & a: $3.70(d, J 10.5)$ & $\mathrm{H}-2^{\prime} \mathrm{b}$ & \\
\hline $2^{\prime} b$ & & b: $3.56(d, J 10.5)$ & $\mathrm{H}-2^{\prime} \mathrm{a}$ & & & b: $3.58(d, J 10.5)$ & $\mathrm{H}-2^{\prime} \mathrm{a}$ & \\
\hline
\end{tabular}

${ }^{\mathrm{a}} \mathrm{H}$ NMR signals assignment was rationalized by HSQC contour map and Perch NMR software calculations.

bInterchangeable signals. 
$(\delta 1.21-2.54 / \delta$ 21.9-39.0) and signals due to a terminal methyl group were observed at $\delta 0.85(1 \mathrm{H}, \mathrm{t}, J=7.0 \mathrm{~Hz}, \mathrm{H}-20)$ and at $\delta 13.9$ (C-20). The similarity between shifts and coupling constants values found in the ${ }^{13} \mathrm{C}$ NMR and ${ }^{1} \mathrm{H}$ spectra of both 1 and 2, at $\mathrm{C}-1$ to $\mathrm{C}-5$ and $\mathrm{H}-3$ to $\mathrm{H}-5$ proton signals, respectively, suggested that these two structural moieties are identical in $\mathbf{1}$ and $\mathbf{2}$. However, the comparison between the $[\alpha]_{\mathrm{D}}$ values for $\mathbf{1}\left(-9.0^{\circ}, \mathrm{c} 0.3\right.$, $\mathrm{MeOH})$ and myriocin $\left(+5.1^{\circ}, \mathrm{c} 0.18, \mathrm{MeOH}\right)^{35}$ shows that they are comparable in magnitude but with opposite signs. This reversal effect on the $[\alpha]$ sign of $\mathbf{1}$ in comparison with $\mathbf{2}$ could result from conformational effects due the double bond at C- $12 .{ }^{36}$ Fujita et al. ${ }^{37}$ also reported that the compound 6,7-dihydromyriocin, obtained by the hydrogenation of myriocin, is a levorotatory compound $\left([\alpha]_{\mathrm{D}}\right.$ $\left.-6.5^{\circ}, \mathrm{c} 0.108, \mathrm{MeOH}\right)$. This sign reversal effect was also found when comparing $[\alpha]_{\mathrm{D}}$ values for myriocin ${ }^{35}$ and 14-epi-mycestericin A. ${ }^{38}$ Thus, the relative stereochemistries at C-2, C-3 and C- 4 of 1 were assigned as $2 S, 3 R$ and $4 R$, respectively. On the basis of these observations, compound $\mathbf{1}$ was identified as $(2 S, 3 R, 4 R)-(E)-2$ amino-3,4-dihydroxy-2-(hydroxymethyl)-14-oxoeicos-6,12-dienoic acid, as shown in Figure 2.

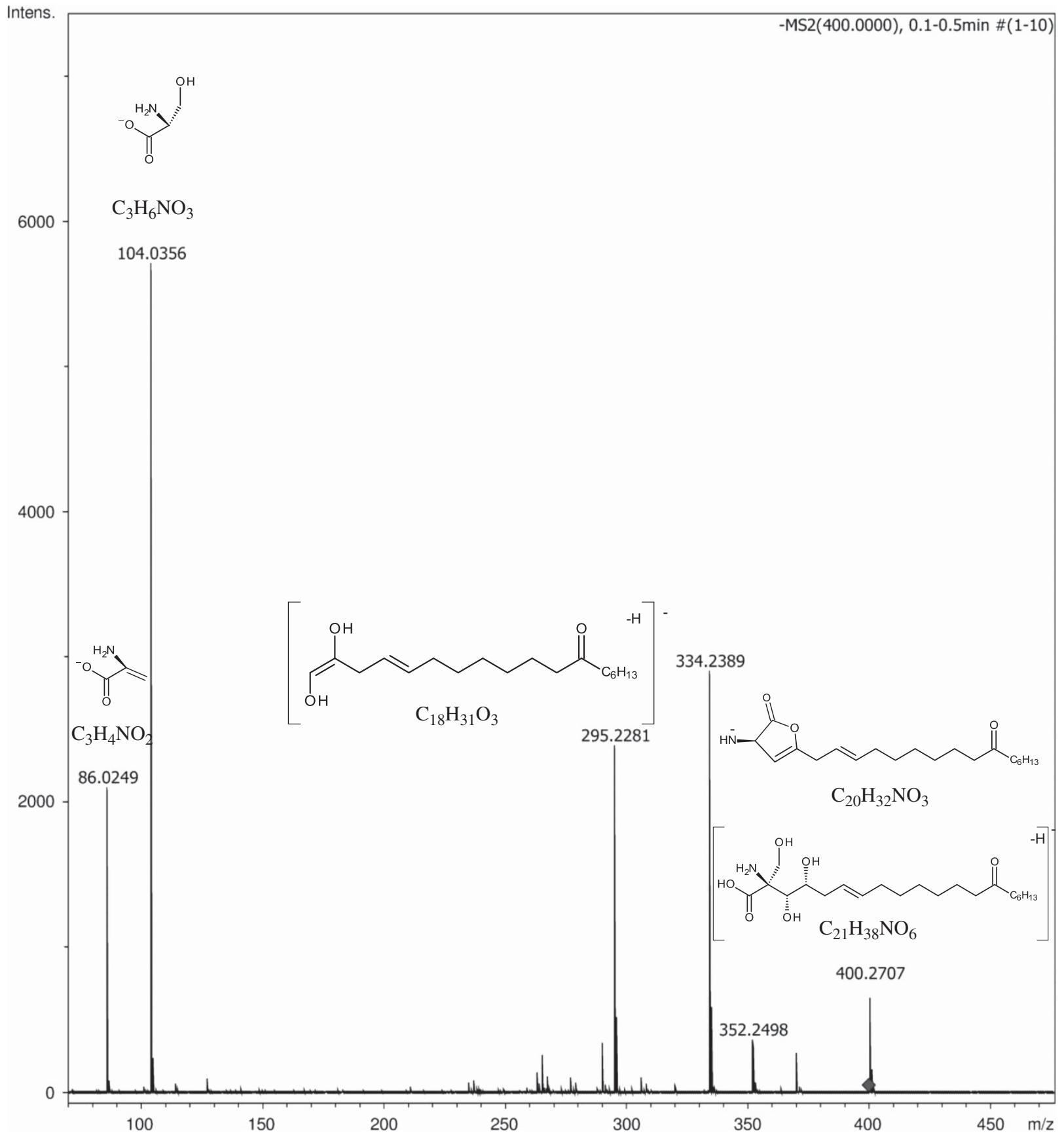

Figure 4 The ESI-(-)-LC-MS/MS spectra of compound 2 and proposal of the key fragments. A full color version of this figure is available at The Journal of Antibiotics journal online. 
Compound 2 was isolated as an amorphous white solid, and the UV spectrum exhibited no absorption maximum above $200 \mathrm{~nm}$. It showed a positive specific rotation $\left([\alpha]_{\mathrm{D}}{ }^{25}+5.1^{\circ}\right.$, c 0.55 in $\left.\mathrm{CHCl}_{3}: \mathrm{MeOH} 1: 1\right)$. The negative HRMS (ESI-QTOF) spectrum of compound 2 showed a quasi-molecular ion peak $[M-\mathrm{H}]^{-}$at $\mathrm{m} / \mathrm{z} 400.2707$ (calcd. 400.2699 for $\mathrm{C}_{21} \mathrm{H}_{38} \mathrm{NO}_{6}$ ), consistent with the molecular formula $\mathrm{C}_{21} \mathrm{H}_{39} \mathrm{NO}_{6}$. The mass spectrum obtained using tandem MS of compound 2 showed an ion peak $[M-\mathrm{H}-296]^{-}$at $\mathrm{m} / z$ 104.0356 (base peak, $\left.\mathrm{C}_{3} \mathrm{H}_{6} \mathrm{NO}_{3}\right)$, and the main fragments at $m / z 334.2389\left(\mathrm{C}_{20} \mathrm{H}_{32} \mathrm{NO}_{3}\right), m /$ $z$ 295.2281 $\left(\mathrm{C}_{18} \mathrm{H}_{31} \mathrm{O}_{3}\right)$ and $m / z 86.0249\left(\mathrm{C}_{3} \mathrm{H}_{4} \mathrm{NO}_{2}\right)$, respectively. The proposal of the key fragments is shown in Figure 4. Analysis of the NMR and HRMS spectra of compound 2 showed that its main difference from compound $\mathbf{1}$ is the absence of a double bond at $\mathrm{C}_{12}-$ $\mathrm{C}_{13}$. Furthermore, the respective ${ }^{1} \mathrm{H}$ NMR spectrum signals for $\mathrm{H}-2^{\prime}$ (a and $b$ hydroxymethylene protons), as well as the $[\alpha]_{D}$ value reported for the isomeric compound 2-epi-myriocin, ${ }^{39}$ differ significantly from those found for compound 2 . On the basis of these observations, 2 was identified as (2S,3R,4R)-(E)-2-amino-3,4-dihydroxy-2-(hydroxymethyl)14-oxoeicos-6-enoic acid, known as (+)-myriocin (2) and shown in Figure 2. All ${ }^{1} \mathrm{H}$ and ${ }^{13} \mathrm{C}$ NMR (one and two dimensional) data for $\mathbf{1}$ and 2 can be seen in Table 4 .

\section{Antifungal activity of isolated compounds}

Mycosphaerella spp. are important phytopathogenic species, causing diseases in wheat, banana, Eucalyptus species and other crops. ${ }^{40,41}$ Bioactive compounds were isolated from other species of $\mathrm{Myco}$ sphaerella. Asteromine, a 6,6'-binaphtho $\alpha$-pyrone isolated from M. asteroma, has antifungal activity against Ustilago maydis, Ophiostoma ulmi and Geotrichum candidum. ${ }^{42}$ Cercosporin, a perylenequinone metabolite of polyketide origin, was isolated from Mycosphaerella sp. nov. strain F2140 associated with the foliage of the plant Psychotria horizontalis (Rubiaceae). Cercosporin exhibits high cytotoxicity activity (MCF-7, $\mathrm{IC}_{50} 4.68 \mu \mathrm{M}$ ) and also non-selective anti-protozoan activity against Plasmodium falciparum $\left(\mathrm{IC}_{50} 1.03 \mu \mathrm{M}\right)$, Leishmania donovani ( $\left.\mathrm{IC}_{50} 0.46 \mu \mathrm{M}\right)$ and Trypanosoma cruzi $\left(\mathrm{IC}_{50} 1.08 \mu \mathrm{M}\right) .{ }^{43}$

In the present work we show that eicosanoic acids, the oxidized derivatives of C20-fatty acids produced by Mycosphaerella sp. UFMGCB 2032, possess antifungal activity. Compound 1 exhibited MIC values of 1.3 and $2.5 \mu \mathrm{g} \mathrm{ml}^{-1}$ against C. neoformans and C. gattii, respectively. Compound 2 showed a MIC value of $0.5 \mu \mathrm{g} \mathrm{ml}^{-1}$ to both species of Cryptococcus tested. The antifungal activity of natural product analogs from the eicosanoid family is still little explored, specifically against Cryptococcus pathogenic species. According to the literature, there are no previous reports of the isolation of compound 1, whereas compound 2 (myriocin) was first described by Kluepfel et al. $^{44}$ and later isolated from Myriococcum albomyces, Melanconis flavovirens, Isaria sinclairii and Paecilomyces variotii ATCC $74097 .{ }^{45}$ They are reported herein for the first time as natural products from this endophytic species. Myriocin is a serine palmitoyltransferase inhibitor $^{46}$ and has immunosuppressant activity. This metabolite also exhibits antifungal properties against several pathogens (Alternaria solani, C. albicans, C. parapsilosis, C. pseudotropicalis, C. tropicalis, Ceratocytis ulmi, Cryptococcus laurentii, Fusarium oxysporum, Rhizomucor miehei and Streptomyces spp..$^{44,47}$

These two eicosanoic-acid compounds exhibited higher antifungal activities against Cryptococcus species than the crude original extract and fractions. Considering the antifungal activity of the compounds demonstrated in this work, their in vivo efficacy in a murine model of Cryptococcus infection should be assessed.

\section{CONFLICT OF INTEREST}

The authors declare no conflict of interest.

\section{ACKNOWLEDGEMENTS}

We thank the 'Conselho Nacional de Desenvolvimento Científico e Tecnológico' (CNPq) for financial support and for a scholarship. This work was also supported in part by a grant from 'Fundação de Amparo à Pesquisa do Estado de Minas Gerais' (FAPEMIG). We thank the Program of Technological Development in Tools for Health PDTIS-FIOCRUZ, RPT13A platform, and especially Eliane G Carvalho for the use of its facilities.

1 Perfect, J. R. et al. Clinical practice guidelines for the management of cryptococcal disease: update by the infectious diseases society of America. Clin. Infect. Dis. 50, 291-322 (2010)

2 Kurtzman, C. P., Fell, J. W. \& Boekhout, T. The Yeasts: a Taxonomic Study (Elsevier: New York, NY, USA, 2011).

3 Rosario, I., Acosta, B. \& Colom, F. La paloma y otras aves como reservorio de Cryptococcus spp. Rev. Iberoam. Micol. 25, S13-S18 (2008)

4 Nucci, M. \& Perfect, J. R. When primary antifungal therapy fails. Clin. Infect. Dis. 46, 1426-1433 (2008).

5 Vandeputte, P., Ferrari, S. \& Coste, A. T. Antifungal resistance and new strategies to control fungal infections. Int. J. Microbiol. 2012: ID 713687 1-26 (2012)

6 Desnos-Ollivier, M. et al. Mixed infections and in vivo evolution in the human fungal pathogen Cryptococcus neoformans. MBio 1, e00091-10 (2010).

7 Del Poeta, M. \& Casadevall, A. Ten challenges on Cryptococcus and Cryptococcosis. Mycopathologia 173, 303-310 (2012).

8 Bacon, C. W. \& White, J. F. Microbial Endophytes (Marcel Dekker: New York, NY, USA, 2000).

9 Strobel, G. A. Endophytes as sources of bioactive products. Microbes Infect. 5, 534-535 (2003)

10 Pimentel, M. R., Molina, G., Dionísio, A. P., Maróstica, M. R. J. \& Pastore, G. M. The use of endophytes to obtain bioactive compounds and their application in biotransformation process. Biotechnol. Res. Int. 2011: ID 576286 1-11 (2011).

11 Vieira, M. L. A et al. Diversity and antimicrobial activities of the fungal endophyte community associated with the traditional Brazilian medicinal plant Solanum cernuum Vell. (Solanaceae). Can. J. Microbiol. 58, 54-66 (2012).

12 Rosa, L. H. et al. Leishmanicidal, trypanocidal, and citotoxic activities of endophytic fungi associated with bioactive plants in Brazil. Braz. J. Microbiol. 41, 420-430 (2010)

13 Carvalho, C. R. et al. The diversity, antimicrobial and anticancer activities of the endophytic fungi associated with the medicinal plant Stryphnodendron adstringens (Mart.) Coville (Fabaceae) from the Brazilian savannah. Symbiosis 57, 1-13 (2012).

14 Eucast-Subcommittee of antifungal susceptibility testing of the European Committee on Antibiotic Susceptibility Testing (EUCAST). Method for determination of Minimal Inhibitory Concentration (MIC) by broth dilution of fermentative yeasts (Document 7.1. Taufkirchen: Germany, ECSMID, 2002).

15 White, T. J., Bruns, T., Lee, S. \& Taylor, J. Amplification and direct sequencing of fungal ribosomal RNA genes for phylogenetics. in PCR Protocols: a guide to methods and applications (eds Innis M. A., Gelfand D. H., Sninsky J. J., White T. J.) 315-322 (Academic Press: San Diego, USA, 1990).

16 Rosa, L. H., Vaz, A. B. M., Caligiorne, R. L. B., Campolina, S. A. \& Rosa, C. A. Endophytic fungi associated with the Antarctic grass Deschampsia antarctica Desv. (Poaceae). Polar Biol. 32, 161-167 (2009).

17 Togawa, R. C. \& Brigido, M. M. PHPH: Web based tool for simple electropherogram quality analysis. Abstracts of Papers of 1st International Conference on Bioinformatics and Computational Biology (IcoBiCoBi, 14th to 16th, Ribeirão Preto, Brazil, 2003).

18 Tamura, K. et al. MEGA5: molecular evolutionary genetics analysis using maximum likelihood, evolutionary distance, and maximum parsimony methods. Mol. Biol. Evol. 28, 2731-2739 (2011).

19 Edgar, R. C. MUSCLE: multiple sequence alignment with high accuracy and high throughput. Nucleic Acids Res. 32, 1792-1797 (2004).

20 Felsenstein, J. Confidence limits on phylogenies: an approach using the bootstrap. Int. J. Evol. 39, 783-791 (1985).

21 Phongpaichit, S., Rungjindamai, N., Rukachaisirikul, V. \& Sakayaroj, J. Antimicrobial activity in cultures of endophytic fungi isolated from Garcinia species. FEMS Immunol. Med. Microbiol. 48, 367-372 (2006).

22 Sun, Z. L., Zhang, M, Zhang, J. F. \& Feng, J. Antifungal and cytotoxic activities of the secondary metabolites from endophytic fungus Massrison sp. Phytomedicine 18, 859-862 (2011)

23 Wang, X. et al. Antifungal activity against plant pathogens of metabolites from the endophytic fungus Cladosporium cladosporioides. J. Agric. Food Chem. 61, 4551-4555 (2013).

24 Vaz, A. B. M. et al. Diversity and antimicrobial activity of fungal endophyte communities associated with plants of Brazilian savanna ecosystems. Afr. J. Microbiol. Res. 55, 62-70 (2012). 
25 Rosa, L. H. et al. Coniochaeta ligniaria: antifungal activity of the cryptic endophytic fungus associated with autotrophic tissue cultures of the medicinal plant Smallanthus sonchifolius (Asteraceae). Symbiosis 60, 133-142 (2013).

26 Fica, A. C. Tratamiento de infecciones fúngicas sistêmicas primeira parte: fluconazol, itraconazol y voriconazol. Rev. Chil. Infectol. 21, 26-38 (2004).

27 Lago, J. H. et al. Chemical and biological evaluation of essential oils from two species of Myrtaceae - Eugenia uniflora L. and Plinia trunciflora (0. berg) Kausel. Molecules 16, 9827-9837 (2011).

28 Stefanello, M. É., Pascoal, A. C. \& Salvador, M. J. Essential oils from neotropical Myrtaceae: chemical diversity and biological properties. Chem. Biodivers. 8, 73-94 (2011).

29 Santos, K. K. et al. Anti-Trypanosoma cruzi and cytotoxic activities of Eugenia uniflora L. Exp. Parasitol. 131, 130-132 (2012).

30 Sharma, S. B., Tanwar, R. S., Nasir, A. \& Prabhu, K. M. Antihyperlipidemic effect of active principle isolated from seed of Eugenia jambolana on alloxan-induced diabetic rabbits. J. Med. Food. 14, 353-359 (2011).

31 Nunez, L., D'Aquino, M. \& Chirife, J. Antifungal properties of clove oil (Eugenia caryophylata) in sugar solution. Braz. J. Microbiol. 32, 123-126 (2001).

32 Sasaki, S. et al. Fungal metabolites. Part 14. Novel potent immunosuppressant mycestericins, produced by Mycelia sterilia. J. Antibiot. 47, 420-433 (1994).

33 Sano, S. et al. Asymmetric total synthesis of ISP-I (myriocin, thermozymocidin), a potent immunosuppressive principle in the Isaria sinclairii metabolite. Tetrahedron Lett. 36, 2097-2100 (1995).

34 Jones, M. C. \& Marsden, S. P. Total synthesis of the immunosuppressants myriocin and 2-epi-myriocin. Org. Lett. 10, 4125-4128 (2008).

35 Fairhurst, N. W. G., Mahon, M. F., Munday, R. H. \& Carbery, D. R. Remote stereocontrol in [3,3]-sigmatropic rearrangements: application to the total synthesis of the immunosuppressant mycestericin G. Org. Lett. 14, 756-759 (2012).

36 Wiberg, K. B., Vaccaro, P. H. \& Cheeseman, J. R. Conformational effects on optical rotation. 3-substituted 1-butenes. J. Am. Chem. Soc. 125, 1888-1896 (2003).
37 Fujita, T. et al. Fungal metabolites. Part 12. Potent immunosuppressant, 14-deoxomyriocin, (2 S, 3 R, 4 R)-(E)-2-amino-3,4-dihydroxy-2-hydroxymethyleicos-6-enoic acid and structure-activity relationships of myriocin derivatives. J. Antibiot. 47, 216-224 (1994).

38 Yamanaka, H. et al. Total synthesis of mycestericin A and its 14-epimer. Tetrahedron 65, $9188-9201$ (2009).

39 Yoshikawa, M., Yokokawa, Y., Okuno, Y., Yagi, N. \& Murakami, N. Syntheses, immunosuppressive activity, and structure-activity relationships of myriocin analogs, 2-epi-myriocin, 14-deoxomyriocin, Z-14-deoxomyriocin, and nor-deoxomyriocins. Chem. Pharm. Bull. 43, 1647-1653 (1995).

40 Park, R. F., Keane, P. J., Wingfield, M. J. \& Crous, P. W. Fungal diseases of eucalypt foliage. in Diseases and Pathogens of Eucalypts (eds Keane P. J., Kile G. A., Podger F. D., Brown B. N.) 153-239 (CSIRO Publishing: Collingwood, VIC, Australia, 2000).

41 Irish, B. M., Goenaga, R., Rios, C., Chavarria-Carvajal, J. \& Ploetz, R. Evaluation of banana hybrids for tolerance to black leaf streak (Mycosphaerella fijiensis Morelet) in Puerto Rico. Crop Prot. 54, 229-238 (2013).

42 Arnone, A., Assante, G., Montorsi, M. \& Nasini, G. Asteromine, a bioactive secondary metabolite from a strain of Mycosphaerella asteroma. Phytochemistry 38, 595-597 (1995).

43 Moreno, E. et al. Chemical constituents of the new endophytic fungus Mycosphaerella sp. nov. and their anti-parasitic activity. Nat. Prod. Commun. 6, 835-840 (2011).

44 Kluepfel, D. et al. Myriocin, a new antifungal antibiotic from Myriococcum albomyces. J. Antibiot. 25, 109-115 (1972).

45 Dictionary of Natural Products on DVD-ROM, version 19.1. (Eds. J. Buckingham) Chapman \& Hall (CRC, Boca Raton, 2013).

46 Castro, E. V. et al. Myriocin, a serine palmitoyltransferase inhibitor, blocks cytokinesis in Leishmania (Viannia) braziliensis promastigotes. J. Eukaryot Microbiol. 60, 377-387 (2013)

47 Horn, W. S. et al. (Merck \& Co., Inc.). Antibiotic eicosenoic acids. US5,233,062A (1993). 